\title{
THE CROCHETING OF THE IMPLEMENTATION OF PANCASILA VALUES ON THE REGIONAL GOVERNMENT BUDGET
}

\author{
Sujatmika*, Ludigdo Unti, Purwanti Lilik, Prihatiningtias Yenney W. \\ Faculty of Economics and Business, University of Brawijaya, Indonesia \\ *E-mail: sujatmika@upnyk.ac.id
}

\begin{abstract}
This study examines how to crochet the implementation of Pancasila values on the regional government budget through a case study in Bantul Regency. The study focused on the implications of implementing Pancasila values which have been carried out at the Regional Government of Bantul as an effort to apply Pancasila in the government. Through the implementation of Pancasila values, it is hoped that Bantul Regency community will be safe, peaceful and prosperous. This study contributes knowledge about the impact of the implementation of Pancasila values in regional government and gives input to the government to apply Pancasila through the budget in accordance with the Minister of Internal Affairs speech, Tjahyo Kumolo (Kedaulatan Rakyat page 7, November 7, 2017) which invites regional government officials to implement Pancasila in their respective regions with regional income and expenditure budgets (APBD).
\end{abstract}

\section{KEY WORDS}

Crocheting, implementation, Pancasila values, regional government.

This article reports and analyzes the implementation of Pancasila values that have been carried out at the Regional Government of Bantul in an effort to apply the values of Pancasila through the budget, because Indonesia is an adequate country to fulfill the requirements of living and living in the world by standing on one's own feet. Without this hard struggle to cultivate Indonesia's earth, it is useless for God of One Almighty to provide all this. The Indonesian people do not depend on someone else's hand or dependence on other nations

The facts show that the Indonesian people are still lacking in development. This indicates that the Indonesian people failed to form a complete human being with the spirit of Pancasila, a philosophy of Pancasila, an ideology of Pancasila and a life view of Pancasila. The community should not be discouraged, because God of One Almighty still provides time to reconstruct the spirit of Pancasila.

The struggle is still long; the Indonesian people must not be complacent to keep the trust that has been given to the Indonesian people. Mistakes, mistakes and ugliness which have been facing the Indonesian nation so far, have to be eroded quickly to welcome tomorrow which is better and prosperous. To realize seriousness in welcoming this free tomorrow, everything is based on the foundation of Pancasila and the Constitution of 1945. This is a manifestation of the independence of the Indonesian nation without any influence from other countries.

This study uses a critical method approach, by criticizing the Regional Government of Bantul managers who have been known to the author, have not implemented Pancasila values. The study data is obtained through interviews with informants and observations as well as documents found in the field.

The most important thing for the Indonesian people is how to rearrange the values of Pancasila in daily life in accordance with the principles (understanding) which remain in the frame with diversity. The Indonesian people need a situation which they feel can alleviate life in the nation and state. Perseverance in living life is indeed expected from the partisanship of leaders in conducting government management in the management of society.

The role of a very large leader in the management of government is namely in an effort to make activities which is based on the values of Pancasila. In government, every leader at 
any level, has inherent responsibility to develop capacity including serving the community and improving the welfare of the community in order to reconstruct people's trust in leaders with frames of diversity and in the grip of Pancasila.

The Implementation of Pancasila Values. Indonesian people love to theorize and speak, making Indonesia rich in brilliant theories and concepts including Pancasila, but very weak in consistent and effective implementation. Great leaders once discourse and do not balance the discourse with concrete action. Ordinary is only imagined so Pancasila values are only stored in the brain without taking action.

The implementation of the contents of the principles of Pancasila in daily life can be prepared and carried out by the community together with regional government as state administrators, state authorities in various fields of life, statehood and other fields. One source referred to is Al-Quran NurKharim and from human thought which a reference for the implementation of Pancasila is.

The First Principle - One Almighty God (QS: Al Ikhlas-1):

Say: He is God of One Almighty.

The main backrest of living people is God of One Almighty. God of One Almighty is omniscient what people do. What people talk about and do in this world, God of One Almighty hears and knows. Likewise without exception when people still live in the world whatever is done needs to be accounted for. The meaning of God of One Almighty, morphologically, contains abstract meanings or things (Ramlan, 1983: 245), namely conformity with the nature of values originating from God of One Almighty and realization in the form of religious values (which come from One Almighty God).

Every Indonesian citizen must believe and believe in God of One Almighty, because Indonesian people realize that God of One Almighty which is a source of life, morality and ethics is very important in all human behavior in Indonesia. For devoted Indonesian people, the main backing in life is God of One Almighty, not other objects or other creatures.

Humans as creatures created by God of One Almighty must worship God of One Almighty creator and respect each other with human beings and the natural environment. The concept aims to create a harmonious relationship between the Creator and people. They are humans and fellow people. Between people and the environment must also respect each other, even with supernatural beings also respect each other. If people do well to their fellow human beings, people will live in peace as well as must be towards the natural environment.

As an Indonesian nation that has different religions and beliefs, even though there are different religions and beliefs, they still work together to help each other and help without seeing any differences between them. Religion is a source of unification in carrying out national development. One cannot force others to embrace religion according to or force someone to move from one religion to another.

From the values contained in God of One Almighty principle, it can be stated that this principle is the basis of spirituality, a moral basis for the Indonesian people in carrying out the life of the state and community (Kaelan, 2009: 150). The value contained in this first principle, can be implemented in regional government in the life of the state which is based on God of One Almighty which means that in making the budget as the implementation of state life, it must pay attention and respect the instructions or laws.

The implementation of this first principle according to the Vice-Regent of Bantul Regency from the results of my interview as an author is:

"Carrying out religious guidance in the community, fostering the implementation of Islamic teachings, facilitating the departure of Bantul Regency pilgrimage, coordinating professional alms for the State Civil Apparatus conducting stimulants for mosque activities and other religions whose outcome is intended to improve faith and belief for God of One Almighty including other religions".

Thus, all religions recognized in the Unitary State of the Republic of Indonesia (NKRI) which reside in Bantul Regency are guaranteed to be able to move and develop well in accordance with the rules of each religion without leaving the rules has been made and agreed upon together with mutual respect and full of tolerance, because freedom of religion is one of the most basic rights, among human rights. The right to religious freedom comes 
from God of One Almighty, not human, state or not giving groups so people are mutually tolerant.

The Second Principle - Just and Civilized Humanity (QS: An Nisa'-135):

So do not follow lust, let you be a justice man.

The justice will be achieved if people understand each other. In this world, there are no smart people and not smart, there are people who understand and do not understand. Human nature as a creature created by God of One Almighty in this world is not useless, but has benefits and has a noble duty as a caliph who upholds justice, not siding with individuals, groups or parties. Indonesian people are obliged and entitled to live freely or permanently (Dipoyudo, 1984: 9).

Humanity in this second principle implies the suitability of the traits and the state of the state with human nature (abstraction). The characteristics and circumstances include the main things of state including the nature of the state, state power, state goals, the system of state administration, matters relating to all aspects of state administration (Notonagoro, 1975: 87). This can be understood, because the essence of the principal supporters of the state is human. Thus, the state in essence is a humanitarian institution that has the duty to act fairly.

In Pancasila values are contained that the state must uphold human dignity and values as civilized beings. Human values which are justice and civilized contain the meaning that human nature as a cultured and civilized creature must be justly based. This contains an understanding that human nature must be fair in relations with oneself, fair to other human beings, fair to society, fair to the environment and fair to God of One Almighty.

The consequence of value which is contained in a justice and civilized humanity is to uphold the dignity and human dignity as God of One Almighty creature, uphold human rights, respect for equal rights and degrees, regardless of ethnicity, race, lineage, status social or religious. In addition, there is also an attitude of mutual love for fellow human beings tolerance, not arbitrary toward fellow human beings, upholding human values (Darmodiharjo, 1996).

The government as the State organizer must describe, carry out and implement these values in filling out national development, especially the moral development of state administrators. The values contained in this second principle for regional government, are carried out in the context of budgeting, that is, they must act fairly in a proportional manner in all fields. The budget must touch the community, fairly and civilized, given the relationship that must be considered between people, the environment and the existence of God of One Almighty which gives life to people on this planet earth.

The implementation of the second principle in Bantul Regency is according to the ViceRegent of Bantul Regency through the results of my interview as an author is:

"Bantul Regency has a regional poverty reduction team, the Coordination Team of Regional Poverty Reduction (TKPKD) with its chairman, Vice-Regent, how regional budget and expenditure can lead to humanitarian interests among them are poverty, helplessness, concrete form: have development assistance uninhabitable homes for the poor, then we have scholarships for the poor, besides programs from the center, such as "community health insurance", the area also has to supplement the program with the name "regional health insurance", other social guarantees, such as assistance for people with disabilities in the form of wheelchairs and medicines, the provision of budgeting for flooring programs for poor people who have houses without floors, those who do not have electricity who do not have baths, there are bathing places as outcome to save basic needs that are very human so that society poor intellect can receive adequate attention".

The People in Bantul Regency do not live alone, but live in a society which requires socialization between people which is in the area, even outside the region with the attention of Bantul Regency government to be inseparable from the environment. In society, people individually, should not be arbitrary and act unfairly, because the essence of human beings born on earth is the same. In terms of justice, regional government will guarantee as a form of carrying out the mandate of the community.

The Third Principle - Indonesian Unity (QS: Al Hujarat-13):

And we make you some tribes so that you know each other. 
During the struggle for Indonesian independence, the notion of Indonesian unity is a key factor, namely as a source of enthusiasm, motivation and drive for Indonesia's struggle. It can be considered in the expression "Anything as heavy as, if we lift together, it will become light, any heavy problem, and if we are a joint solution / unity will become liquid" Unity, morphologically, means a result of actions. So, it is a noun. In terms of dynamics, the notion of unity is a dynamic process. In 'Indonesia' is a quantity. This means, unity for the region, nation and state of Indonesia (Kaelan, 2009: 179).

The third principle contains the value that the state is the incarnation of the nature of human mono-dualists, namely as individual beings and social beings. Indonesian people have never lived alone, but always lived in unity with other people. The value contained in this third principle is that people in living in a society must develop an attitude of cooperation for unity in a shared life to realize a common goal.

Indonesian people understand and uphold every outcome of deliberation decisions, therefore all parties concerned must accept and implement with good intentions, sincerity and full of responsibility. This shows that the Indonesian people uphold common interests, not personal, group or group interests. The meaning of Indonesian unity is that the nature and state of Indonesia must be in accordance with the nature of one ${ }^{1}$. The State of Indonesia is a personal self which has its own characteristics, characteristics and character which means having a unity and not being divided.

The values contained in this third principle, by regional government, are implemented when preparing a budget which is a consideration, by making and considering, the attitude of cooperation and harmony, not for individuals or groups that can divide. The budget is not for certain elites, but is made for the welfare of society.

The implementation of the third principle in Bantul Regency is according to the ViceRegent of Bantul Regency through the results of my interview as author is:

"We have budgetary activities available for the building of harmony in religious life, there is a FKUB (Religious Harmony Forum) given stimulants for conducting meetings, outbound discussions among religious followers, there is also a budget for handling social conflicts whose outcomes are how We can realize this community unity, this is justice an example, because there are too many, I justice want to state that the regional income and expenditure budget in Bantul Regency, if it is drawn to the principle of Pancasila is there ".

On the basis of nationalism which means that the entire Indonesian nation including Bantul Regency must foster close unity between fellow citizens, regardless of ethnicity, class, religion with a united determination and a common ideal. Unity has the meaning of being united in various kinds of patterns which are diverse into one determination. In other words, the unity in Bantul Regency is something diverse, after being united into something that is harmonious intact and not contradictory and messy, between each other.

The Fourth Principle - Citizenship led by Wisdom in Deliberations / Representatives (QS: Ash Syuro-38):

While their affairs (decided) with deliberations between them.

The nature and nature of the state relating to the basis of State politics, enables the realization of a democratic basis for the country of Indonesia. Based on popular principles led by wisdom in deliberations / representatives, the Unitary State of the Republic of Indonesia became a mono-dualist democracy. In a democracy, don't be human beings to always win in every debate, because it cools the brain, more than winning the debate.

This fourth principle contains the value that people are not greedy, prioritize wisdom and prioritize deliberation in making decisions. The leader who is given the trust is a leader who can outline the values of the fourth principle in Pancasila. The value of democracy which must absolutely be carried out in the life of the state and society is a democracy that is not only based on individual freedom, but also based on conscience.

The main essence of this fourth principle which is populist means that the suitability of the nature of the state and nature of the state with the nature of the people cannot be separated from human nature, namely the human basis contained in the second principle of

\footnotetext{
${ }^{1}$ The essence of one means that the absolute cannot be divided.
} 
Pancasila (Kaelan, 2009: 210). In terms of nature and nature, human nature is the basis, because the essence of the principal supporters of the state is human.

Indonesia people understand and uphold every outcome of deliberation decisions. For this reason, all parties involved must accept and implement with good intentions and full responsibility. This means that shared interests are prioritized over personal or group interests. Talks to determine decisions in deliberation, based on common sense and in accordance with a noble conscience.

The values contained in the fourth principle in regional government must be implemented by a leader in the district as the trusted to carry out the mandate. Budget planning and implementation must pay attention to the needs and interests of the public in general. Likewise, people's representatives who sit in the House of Representatives (DPR) in considering the budget, they must also prioritize the people, not prioritize groups or individuals and groups and political parties.

Thus, the regional government in preparing the budget is based on the attitude of democratic deliberation, namely the attitude to base on majority with the principle of majordemocracy with a system of expansion of public participation. This principle indicates that deliberation is needed in preparing the government budget.

The implementation of the fourth principle in Bantul Regency is according to the ViceRegent of Bantul Regency through the results of my interview as author is:

"In budgeting forums, starting from village level budgeting we emphasize discussion and we provide assistance and provide guidance, how to develop development plans at the village level through deliberations so there are instructions for implementing deliberations so that development in the village really based on the aspirations of the people, such as in the Indonesian Youth National Committee (KNPI), youth organization and institutions that have the potential to be invited to develop the community".

The basis of consensus or democracy shows that the Unitary State of the Republic of Indonesia adheres to the notion of democracy. Understanding democracy means that the highest authority (sovereignty) to regulate the state and the people lies in the hands of all the people, not least in Bantul Regency, also doing the basis of consensus agreement.

This consensus meeting is sought in making all decisions, by means of deliberation to reach consensus, among all parties. If this cannot be achieved immediately, then the meeting leader can work with efforts so that the meeting can successfully reach consensus.

The Fifth Principle - The Social Justice for the Entire Indonesian People (QS: An Nahl-90):

Really God of One Almighty tells (you) to be fair and do well.

The justice in nature cannot be understood, if only based on an understanding that is very narrow. To be more profound, it is necessary to do a real action as an effort to provide justice which is based on the character of the Indonesian people. Dividing evenly is easier, but dividing the fair is more difficult, especially the inner birth justice.

The essence contained in this fifth principle, namely justice which means it contains the meaning of conformity and nature with fair nature. The consequences in every aspect of State administration must always be based on the values of justice (Kaelan, 2009: 228). In realization in living together (community), nation and State, there are three kinds of justice relations; it is mentioned as the relationship of triangular justice, namely distributive justice, obedience justice and commutative justice.

By referring to triangular justice, every aspect of the administration of the State in the realization of justice will always materialize these three aspects of justice, the realization of which is a relationship of justice, between state and citizens (distributive justice), between citizens and states (obedience justice) and between fellow citizens (commutative justice) (Notonagoro, 1975: 141-142)

The values which are contained in this fifth principle, explain that Indonesian human beings from birth developed as individuals who have personality as well as being social human beings who seek the welfare of society, the nation and humanity. Not people who can freely and arbitrarily treat other people, because of interests. Not prosperous and fair for some groups or groups. Such a thing is not a mirror of the fifth principle of Pancasila. 
The justice that must be realized in value in this fifth principle is justice in shared life (social life). This justice is based and inspired by the nature of humanitarian justice, namely justice in the relationship between man and himself, people and other people, people and society, nation and state and human relations with God of One Almighty (Kaelan, 2014: 77). The value of justice must be a basis which must be realized in living together with the state to realize the goals of the country, namely the welfare of all citizens and protect all citizens and regions and educate all citizens.

The values contained in the fifth principle for regional government in preparing programs and budgets, are applied in a truly fair manner, namely fair distributive, fair compliance and commutative fair for all Indonesian people. For this reason, fairness must be developed towards others, maintaining continuity between rights and obligations and respecting the rights of others. Prioritizing shared interests without abandoning individual interests is a characteristic of the Indonesian nation's personality.

The implementation of the second principle in Bantul Regency is according to the ViceRegent of Bantul Regency through the results of my interview as author is:

"This social justice also complements the second principle, talking about social justice in the regional income and expenditure budget which translates into the rights of all the people of Bantul Regency, from the right to basic services in the form of health, education then a decent life, if poor really has to be guaranteed, starting from housing insurance, health insurance through "regional health insurance" and education given a scholarship or being released, then other public services, then addressed and improved so that more justice is achieved well".

In a speech on June 1,1945, President Sukarno stressed that the principle of welfare is the principle of no poverty in the realm of an independent Indonesia. At Bantul Regency, this welfare principle is also a concern. Social justice is the nature of a justice and prosperous society, happiness for everyone, no occupation, no humiliation, all happy, enough clothes, food and housing.

The Crocheting of the Implementation of Pancasila Values. For 19 years after the reformation, the implementation of Pancasila values felt increasingly fading. In fact, the hum of Pancasila also began to be heard. Therefore, it is necessary to strive to remember and apply again in earnest. As citizens of Indonesia, let's together, begin to reinvest the spirit of the soul and the implementation of the values of Pancasila in the life of the nation and state.

Most people may consider that Pancasila is only a point of thought, from the Indonesian founding fathers. The thing that is often overlooked is that Pancasila is a collective experience in Indonesian society for hundreds of years. Even Pancasila have existed since the kingdom and is carried out by the rulers at that time.

Pancasila is born, because President Sukarno deeply understood the conditions of the people of Indonesia which are diverse and varied, namely differences in ethnic groups, religions, beliefs, customs, languages islands and traditional customs. With the birth of Pancasila, President Sukarno hoped that the Indonesian people could be safe, harmonious and sentimental and united. Minister of Internal Affairs, Tjahyo Kumolo (Kedaulatan Rakyat page 7, November 7, 2017) invites regional government officials to implement the implementation of Pancasila in their respective regions with a regional income and expenditure budget. The government can also run the government based on Pancasila. With Pancasila foundation it is hoped that it can create a peaceful, peaceful and harmonious atmosphere for the life of the nation and state.

Pancasila is a strong Indonesian identity. Pancasila is able to make the Indonesian people who are of various ethnic groups, religions, beliefs and others become united. The Indonesian nation at that time considered the difference to be the beauty and gift of God of One Almighty which must not be contested or debated. The difference between the Indonesian people is used as a united starting point with the slogan "Unite we are firm we separate we collapse".

Indonesia has become strong, because it has Pancasila ideology which comes from the composition of the history and culture of the Indonesian nation itself. Pancasila is an ethical system and a system of community action which can make Indonesia a developed, 
united sovereign, justice and prosperous nation. Pancasila can also be used as a reference in uniting the nation. Therefore, rearranging the values of Pancasila is a demand of the present in achieving a united, developed sovereign, justice and prosperous country in accordance with the ideals of the proclamation of 17 August 1945.

With Pancasila the Unitary State of the Republic of Indonesia is able to unite hand in hand, harmoniously and peacefully. This must be able to make a handle for the nation and state of Indonesia to re-formulate the values of Pancasila in daily life. As a young heir of the nation, it is obligatory to preserve and implement Pancasila in the context of daily life, according to current situations and conditions. Pancasila is an ancestral spirit, ancestors could have died, but their work would not die through the arrangement of Pancasila values so that the Indonesian people would remain the Unitary State of the Republic of Indonesia.

Therefore, all Indonesian people have a responsibility in accordance with their respective capacities to care for and maintain the integrity of the Unitary State of the Republic of Indonesia. The process of developing values which is the basis of that character requires a continuous process and the present. The young generation as the nation's successor must be motivated and triggered to create actions to build civilization with Pancasila foundation. Here the young generation as a strong cadre of the nation is needed as a relay process to crochet, practice and implement Pancasila values.

Conclusion. At this time the people of Indonesia are being hit by a wave of global capitalism which is not in favor of society in general. The Indonesian nation has lost the orientation of Pancasila as the ideology of the nation, the noble ideals of national life in accordance with the message of the opening of the Constitution of 1945 which has long been used as a source of direction for the nation and state. The wave of liberalization, slowly, but surely will affect the lives of nations and countries for the people of Indonesia.

As a great nation and country of Indonesia does not despair to face such an age and wave, because the Indonesian nation still has an ideology which is able to revive it to fight the tide of capitalism. The Indonesian nation also has figures with thoughts that are recognized by other countries, even by the international community who can revive the spirit of struggle, because of the prosperity of the nation and the Unitary State of the Republic of Indonesia. President Sukarno is a figure who has thoughts to fight capitalism and imperialism.

To neutralize the wave of global capitalism, leadership and character are needed to be able to make policies which are oriented towards efforts to protect the interests of the nation and the state and prioritize the interests of the people. Such leaders who are supported by the community to give enthusiasm towards a justice and prosperous society, President Sukarno as a Pancasila digger, still inherits values that are still relevant to face the tide of capitalism which needs to be lifted to the territory of Indonesia again. President Sukarno's teachings that are valuable while functioning to build modern Indonesian tribes are still stored in the minority of the people who want to restore the integrity of the Unitary State of the Republic of Indonesia based on Pancasila.

In the midst of a global situation in various aspects of life in a society that is full of pessimism about life social, economic and cultural, there are even social tensions between groups, between religions, between ethnic groups, caused by problems of justice, values the value of Pancasila in Bantul Regency is still relevant to reconstitute it through the implementation of Pancasila. As a consequence of practicing Pancasila values together, Bantul Regency society must be brave in the front guard to call more loudly in the public space to face globalization, pessimism and tension by rearranging ${ }^{2}$ values Pancasila with the frame of Unity in Diversity (Bhineka Tunggal Ika) which is already owned by the Unitary State of the Republic of Indonesia. Pancasila is a seed that is spread by ancient Indonesian people whose strength has been tested.

\footnotetext{
${ }^{2}$ Crocheting, other terms, networking or make networking.
} 


\section{REFERENCES}

1. Abdulgani, R. (1964). Resapkan and Amalkan Pancasila (11th Ed.). Jakarta: B.P. Prapanca.

2. Abdulgani, R. (1979). Pengembangan Pancasila di Indonesia. Jakarta: Yayasan Idayu.

3. Abdullah, S. (1984). Pancasila Sebagai Dasar Negara and Pandangan Hidup Bangsa. Jakarta: CV. Rajawali.

4. Abdullah, S. (2004). Perilaku Oportunistik Legislatif dalam Penganggaran Daerah: Pendekatan Principal-Agent Theory. Makalah disajikan pada Seminar Antarbangsa di Universitas Bengkulu, Bengkulu, 4-5 Oktober 2004.

5. Alasuutari, P. (2004). Sosial Theory and Human Reality. London: Sage Publications.

6. Ali, As'ad, S. (2009). Negara Pancasila, Jalan Kemaslahatan Berbangsa. Jakarta: LP3ES.

7. Amaliah, T.H. (2014). Konsep Harga Jual Berbasis Nilai-nilai Budaya Komunikasi Papalele Masyarakat Maluku. Malang: Fakultas Ekonomi and Bisnis, Universitas Brawijaya,.

8. American Accounting Association-1966. (1977). A Statement of Basic Accounting Theory, American Accounting Association Committee to Prepare A Statement of Basic Accounting Theory. Boston: Allyn \& Bacon A.

9. American Accounting Association-1966. (1987). Concepts And Standards Research Study Committee, The Realization Concept, Acounting Theory; Text and Reading. 3rd Edition. New York: Scoeder, Mccullers, Clark Jhon Wiley and Sons.

10. Anggarini, Y., and Hendra. (2010). Anggaran Berbasis Kinerja: Penyusunan APBD Secara Komprehensif. Yogyakarta: UPP STIM YKPN.

11. Aziz, A., and Bungin, B. (2005). Menyusun Rancangan Penelitian Kualitatif, Analisa Data Penelitian Kualitatif. Jakarta: PT. Raja Grafindo Persada.

12. Aziz, M. (2017). Merawat Kebhinekaan Pancasila, Agama and Renungan Perdamaian. Jakarta: Gramedia.

13. Bakry, N.M. (2014). Pendidikan Pancasila. Yogyakarta: Pustaka Pelajar.

14. Bararoh, T. (2013). Kontruksi Pengelolaan Keuangan Daerah Berbasis Marhaenisme. Malang: Fakultas Ekonomi and Bisnis, Universitas Brawijaya.

15. Bararoh, T. (2014). Eksplorasi Nilai-Nilai Marhaen dalam Penganggaran Daerah. dalam Seminar Nasional and Call for Paper. Malang: Program Studi Akuntansi-FEB, UMS.

16. Barker, E. (196)7. Principles of Social and Political Theory. Oxford: Oxford University Press.

17. Bastian, I. (2006). Akuntansi Sektor Publik: Suatu Pengantar. Jakarta: Erlangga.

18. Baswir, R. (1997). Akuntansi Pemerintahan Indonesia. Yogyakarta: BPFE.

19. Bendor, J. (1988). Review Article: Formal Models of Bureaucracy. British Journal of Political Science. 18 Juli, hal. 353-395.

20. Bercoff J.J, and Meloni, O. (2009). Federal Budget Allocation in an Emergent Democracy: Evidence from Argentina. New York: Econ Gov 10:65-83.

21. Berg, B.L. (2001). Qualitative Research Methods for the Social Sciences. Boston: Allyn \& Bacon $A$.

22. Burrel, G., and Morgan, G. (1994). Sociological Paradigms And Organizational Analysis; Elements of The Sociological of Corporate Life. New York: Arena, USA.

23. Chua, W.F. (1986). Radical Development in Accounting Thougt. The Accounting Review, Vol. 61, No. 4, 601-632.

24. Connolly, C., and Hyndman, N. (2006). The Actual Implementation of Accruals Accounting: Caveats From a Case Within The UK Public Sector. Accounting, Auditting \& Accountability Journal (19): 272-290.

25. Creswell, J.W. (2007). Qualitative Inquiry \& Research Design: Choosing among Five Approaches. Thousand Oask. London, New Delhi: Sage Publication. 
26. Damayanti, R.A. (2010). Hubungan Keagenan Pemerinhtah Daerah dalam Konteks Anggaran: Sebuah Agenda Rekonstruksi. Malang: Fakultas Ekonomi, Universitas Brawijaya.

27. Deegan, C. (2004). Financial Accounting Theory. Australia: Mc Graw-Hill.

28. Defenbach, T. (2009). New Public Management in Public Sector Organizations: The Dark Sides of Managerialistic 'Enlightenment'. Public Administration. Vol. 87. No. 4: 892-909.

29. Departemen dalam Negeri RI, Lembaga Administrasi Negara RI. (2007). Akuntansi Pelaporan and Pertanggungjawaban Anggaran/ Keuangan Daerah: Diklat Teknis Perencanaan and Pengelolaan Keuangan (Financial Planning and Management). Jakarta: Depdagri.

30. Departemen dalam Negeri RI. (2007). Sistem and Prosedur Pengelolaan Keuangan Daerah Tata Usaha Keuangan Daerah. Jakarta: Depdagri.

31. Dipoyudo, K. (1984). Pancasila Arti and Pelaksanaannya. Jakarta: PT. Gramedia.

32. Emzir. (2012). Metode Penelitian Pendidikan: Kuantitatif and Kualitatif. Jakarta: Raja Grafindo Persada.

33. Goddard, A. (2004). Budgetary Practices and Accountability Habitus: A Grounded Treory, Accounting, Auditing and Accontability Journal. Vol. 17 No. P. 543-77.

34. Grojer, J.E., Stark, A. (1977). Social Accounting: A Swedish Attempt. Accounting, Organizations and Society, Vol. 2. No. 4, pp. 349-386.

35. Gunadi, T. (1995). Ekonomi and Sistem Ekonomi Menurut Pancasila and UUD 1945 (Vol. 1). Bandung: Angkasa.

36. Hadi, P. (2010). Pengelolaan Keuangan Daerah. Jakarta: Salemba Empat.

37. Hafsah, M.J. (2013). Strategi Pembudayaan Nilai-Nilai Pancasila di Bidang Pendidikan and Kebudayaan dalam Perspektif Ke-Indonesia-an. Kongres Pancasila 5. Yogyakarta: Pustaka Pelajar.

38. Halim, A., and Syamkusufi. (2012). Akuntansi Sektor Publik. Jakarta: Salemba Empat.

39. Halim, A., and Syukriy, A. (2006). Hubungan and Masalah Keagenan di Pemerintahan Daerah: Sebuah Peluang Penelitian Anggaran and Akuntansi. Jurnal Akuntansi Pemerintah, 2(1): 53-64.

40. Hanif, L.U., Rahman, A. F., and Baridwan, Z. (2013). Refleksi Nilai-Nilai Pancasila dalam Akuntansi Bagi Hasil. Manado: Simposium Nasional Akuntansi 16.

41. Hariyono. (2014). Ideologi Pancasila Roh Progresif Nasionalisme Indonesia. Malang: Intrans Publishing.

42. Hasanah, N., and Fauzi, A. (2016). Akuntansi Pemerintahan. Jakarta: In Media.

43. Hatta, M. (1957). Tanggung Djawab Moril Kaum Intelegensia. Jakarta: Penerbit Fasco.

44. Heywood, A. (2012). Political Ideologies: An Introduction. New York: Palgrave Macmillan.

45. Pemerintah Kabupaten Bantul. (2018). http://dppkab.bantulkab.go.id/. Bantul: Pemkab.

46. Jones, P. (1993). Combating Fraud and Corruption in the Public Sector. London: Chapman \& Hall.

47. Kaelan. (2009). Filsafat Pancasila, Pandangan Hidup Bangsa Indonesia. Yogyakarta: Paradigma.

48. Kaelan. (2013). Negara Kebangsaan Pancasila. Yogyakarta: Paradigma.

49. Kaelan. (2016). Pendidikan Pancasila. Edisi Revisi Kesebelas. Yogyakarta: Paradigma.

50. Kementerian Dalam Negeri Republik Indonesia. (2003). Undang-Undang Dasar 1945 and Amandemennya. Jakarta: Kemendagri RI.

51. Kementerian Dalam Negeri Republik Indonesia. (2004). Undang-Undang Nomor 32 Tahun 2004 tentang Pemerintah Daerah. Jakarta: Kemendagri RI.

52. Kementerian Dalam Negeri Republik Indonesia. (2004). Undang-Undang Nomor 33 Tahun 2004 tentang Perimbangan Keuangan antara Pemerintah Pusat and Pemerintah Daerah. Jakarta: Kemendagri RI.

53. Kementerian Dalam Negeri Republik Indonesia. (2006). Peraturan Menteri dalam Negeri Nomor 26 Tahun 2006 tentang Pedoman Penyusunan APBD tahun 2007. Jakarta: Kemendagri RI. 
54. Kementerian Hukum and Ham Republik Indonesia. (2005). Pembukaan UndangUndang Dasar Republik Indonesia Tahun 1945. Jakarta: Kemenkumham RI.

55. Kenis, I. (1979). Effects of Budgetary Goal Characteristic on Managerial Attitudes and Performance. The Accounting Review. Vol.54/4: 707-721.

56. Kren, L. (1992). Budgetary Participation and Managerial Performance. The Impact of Information and Enviromental Volatility. The Accounting Review. Vol.67 No.3.

57. Latif, Y. (2011). Filsafat Pancasila. Jakarta: Idayu Press.

58. Latif, Y. (2012). Negara Paripurna Historisitas, Rasionalitas, and Aktualitas Pancasila. Jakarta: PT. Gramedia.

59. Latif, Y. (2015). Revolusi Pancasila. Jakarta: Mizan.

60. Ludigdo, U. (2012). Memaknai Etika Profesi Akuntansi Indonesia Dengan Pancasila. Pidato Pengukuhan Jabatan Guru Besar. Malang: Fakultas Ekonomi and Bisnis, Universitas Brawijaya.

61. Manning, C., and K. Roesad. (2006). Survey of Recent Developments. Bulletin of Indonesia Economic Studies. Agustus. Hal. 143-170.

62. Manning, N. (2000). The New Public Management and Its Legacy. Available from The World Bank: www1.world bank.org/publicsector/civilservice.

63. Mardiasmo. (2002). Otonomi \& Manajemen Keuangan Daerah. Yogyakarta: Andi Offset.

64. Mardiasmo. (2009). Akuntansi Sektor Publik. Yogyakarta: Andi Offset.

65. Merriam, S.B. (2002). Assesing and Evaluating Qualitative Research. In S.B.M. a Assosiates (Ed), Qualitative Research In Practice: Examples for Discussion and Analysis. New York: McGraw Hill.

66. Miles, M.B., and Huberman, M.A. (1984). Qualitative Data Analysis A Source book of New Methods. Baverly Hills, London: Sage Publications.

67. Moleong, L.J. (2004). Metodologi Kualitatif. Bandung: PT Remaja Rosdakarya.

68. Mubyarto. (2004). Revolusi Menuju Sistem Ekonomi Pancasila. Yogyakarta: Aditya Media.

69. Munir., S U., and Suratman. (2016). Pendidikan Pancasila. Malang: Madani Media.

70. Nadhirah, N. (2012). Analisis Fungsi Anggaran Sebagai Alat Pengendalian Belanja Barang and Jasa Pemerintah Daerah. Journal ASSETS Volume 2 Nomor 2.

71. Neuman, W.L. (2006). Social Research Method: Qualitative and Quantitative Approach (Penerjemah, Trans). Boston: Pearson Education Inc.

72. Nordiawan, D. (2009). Akuntansi Sektor Publik. Jakarta: Salemba Empat.

73. Notonagoro. (1971). Pancasila Secara IImiah Populer. Jakarta: Pantjuran Tujuh.

74. Notonagoro. (1974). Pancasila Dasar Falsafah Negara. Jakarta: Bina Aksara.

75. Notonagoro. (1975). Pancasila Secara IImiah Populer. Jakarta: Pantjuran Tujuh.

76. Notonagoro. (1980). Beberapa Hal Mengenai Falsafah Pancasila. Cetakan 9. Jakarta: Pantjuran Tujuh.

77. Notonagoro. (1995). Pancasila Secara Ilmiah Populer. Jakarta: Bumi Aksara.

78. Nurhidayati, L.L., and Yaya, R. (2016). Alokasi Belanja Modal Untuk Pelayanan Publik: Praktik di Pemerintah Daerah. Jurnal Akuntansi \& Auditing Indonesia, 17(2).

79. Parikesit. (2012). Dekontruksi Laba dalam Perspektif Pancasila. Malang: Universitas Brawijaya.

80. Razak, A. (2011). Perilaku Kuasa Eksekutif and Legeslatif dalam Proses Penyusunan Anggaran Pemerintah Daerah: Perspektif Interaksionisme Simbolik Studi Kasus di Pemerintah Kota Mayapada. Malang: Fakultas Ekonomi and Bisnis, Universitas Brawijaya.

81. Rindjin and Ketut. (2012). Pendidikan Pancasila Untuk Perguruan Tinggi. Jakarta: PT Gramedia Pustaka Utama.

82. Roza, P., Jusuf, A.G., and Munaf, D.R. (2015). Memahami and Memaknai Pancasila sebagai Ideologi and Dasar Negara. Jakarta: PT Gramedia Pustaka Utama.

83. Said and As'ad, A. (2009). Negara Pancasila Jalan Kemaslahatan Berbangsa. Jakarta: Pustaka LP3ES. 
84. Salampessy, Z. (2011). Konsep Kepemilikan dalam Akuntansi Berdasarkan Falsafah Pancasila. Malang: Program Strata 2 Universitas Brawijaya.

85. Sanderson, I. (2001). Performance Management, Evaluation and Learning in 'Modern' Local Government. Public Administration,79, 2, 297-313.

86. Sarker, A. (2005). New Public Management, Service Provision and Non-Governmental Organizations in Bangladesh. Public Organization Review,5,3,249-71.

87. Sayidiman, S. (2014). Mengobarkan Kembali Api Pancasila. Jakarta: PT Kompas Media Nusantara.

88. Shelto, C.A. (2007). The Size and Composition of Government Expenditure. Jurnal Public Econ 91:2230-2260.

89. Shi, M., and Svensson, J. (2006). Political Budget Cycles: Do They Differ Across Countries and Why? Jurnal Public Econ 90:1367-1389.

90. Skalen, P. (2004). New Public Management Reform and the Construction of Organizational Identities. International Journal of Public Sector Management, 17, 3, 251-63.

91. Soekarno. (1989). Pancasila and Perdamaian Dunia. Jakarta: CV Haji Masagung.

92. Solichin, M., and Suhartono, E. (2006). Pengaruh Kejelasan Sasaran Anggaran Terhadap Senjangan Anggaran Instansi Pemerintah Daerah dengan Komitmen Organisasi sebagai Pemoderasi. Padang: Simposium Nasional Akuntansi IX 23-26 Agustus 2006.

93. Sopanah. (2013). Partisipasi Masyarakat dalam Proses Penganggaran Daerah Berbasis Kearifan Lokal. Malang: Fakultas Ekonomi and Bisnis, Universitas Brawijaya.

94. Sudjito. (2016). Opini Publik. Yogyakarta: Kedaulatan Rakyat.

95. Sudjito. (2014). Pancasila in the War of Ideology. Yogyakarta: Center for Pancasila Studies Universitas Gadjah Mada.

96. Sugiyono. (2014). Memahami Penelitian Kualitatif. Bandung: CV. Alfabeta.

97. Sunoto. (1991). Mengenal Filsafat Pancasila I: Pendekatan melalui Metafisika, Logika and Etika. Yogyakarta: PT. Hanindita.

98. Suojanen, W.W. (1954). Accounting Theory and The Large Corporation. The Accounting Review, Volume 29, issue 3, 391-398.

99. Suryohadiprojo, S. (2014). Mengorbankan Kembali Api Pancasila. Jakarta: PT. Kompas Media Nusantara.

100. Sutoro, E. (2008). Pro Poor Budget: Politik Baru Reformasi Anggaran Daerah untuk Pengurangan Kemiskinan, Ire's Insinght Working, Paper/Eko/I/February/2008. Institute for Research and Empowerment (IRE). Yogyakarta: Universitas Gadjah Mada.

101. Swasono, E. (2013). Pancasila and Tanggung Jawab Intelektualitas Kita Pendekatan Teoritis Akademis and Ideologis. Kongres Pancasila 4.Yogyakarta, 31 Mei-01 Juni 2012.

102. Syahrial, S. (2014). Pendidikan Pancasila di Perguruan Tinggi (Implementasi Nilai-Nilai Karakter Bangsa). Jakarta: Ghalia Indonesia.

103. Syarifuddin. (2010). Konstruksi Kebijakan Anggaran: Aksentuasi Drama Politik and Kekuasaan Studi Kasus Kabupaten Jembrana Bali. Malang: Fakultas Ekonomi and Bisnis, Universitas Brawijaya.

104. Triyuwono, I. (2013). Makrifat Metode Penelitian Kualitatif and Kuantitatif Untuk Pengembangan Disiplin Akuntansi. Manado: Simposium Nasional Akuntansi 16.

105. Wijoya, S. (2008). Pemahaman Nilai Luhur Pancasila dari Anak Bangsa Ribuan Pulau. Medan: CV. Pelita Buana.

106. World Bank. (1998). Public Finance and Good Governance, (research report). Jakarta: Bappenas. 